\title{
Antiulcerogenic Effects of Selected African Nightshades (Solanum nigrum Linn.) Genotypes on the Rat Stomach: A Morphologic and Morphometric Study
}

\author{
Efectos Antiulcerogénicos de Genotipos Seleccionados de Solanáceas Africanas (Solanum \\ nigrum Linn.) en el Estómago de Ratas: Un Estudio Morfológico y Morfométrico
}

Pauline M. Mureithi ${ }^{1}$; Boniface M. Kavoi ${ }^{1}$; Cecilia M. Onyango ${ }^{2}$ \& Mbaabu P. Mathiu ${ }^{1}$

MUREITHI, P. M.; KAVOI, B. M.; ONYANGO, C. M. \& MATHIU, M. P. Antiulcerogenic effects of selected African nightshades (Solanum nigrum linn.) genotypes on the rat stomach: A morphologic and morphometric study. Int. J. Morphol., 38(4):940-946, 2020.

SUMMARY: Solanum nigrum (SLN), commonly known as African nightshade, is used as a vegetable as well as in the management and treatment of various ailments including gastric ulcers. We analyzed, both grossly and microscopically using H\&E, Masson's trichrome and PSA staining methods, the protective effects of aqueous leaf extracts of three Kenyan SLN genotypes namely S. scabrum (SSB), S. sarrachoides (SSR) and S. villosum (SVL) on ethanol-induced gastric lesions in rats. There was evidence of gastro-protection by all the three genotypes with the SSB showing the highest ulcer inhibition score (76.37\%) followed by SSR $(72.51 \%)$ and SVL $(63.30 \%)$. SLN-pretreated rats showed less areas of gastric mucosal surface erosion. Additionally in the pretreated animals, the depth of the ulcers were markedly reduced, reaching only the gastric pit region except in those treated with SVL where the ulcers penetrated slightly more deeply to affect the gastric glands. Compared with controls, the mean microscopic ulcer index decreased 5.07, 3.55 and 2.37-fold in rats pretreated with SSB, SSR and SVL extracts respectively. Results of this work show extracts of the three SLN genotypes to have antiulcerogenic potential but at varied strengths, thus confirming earlier reports that phytoconstituents and hence the efficacy of a medicinal plant may be influenced by genetic factors.

KEY WORDS: Gastric ulcer; Inhibition; Kenyan; Solanum nigrum.

\section{INTRODUCTION}

Gastric ulceration refers to lesions on the glandular part of the gastric mucosa induced by exposure to excessive hydrochloric acid and pepsin activity (Sabiu et al., 2015). Common causes of gastric lesions include Helicobacter pylori infection, stress, nutritional deficiencies and chemical injury associated with the use of NSADs, which are commonly used to manage musculoskeletal diseases such as arthritis (Moore et al., 2014). Ulceration studies show the rat to be uniquely susceptible to gastric lesions (Greaves, 2012), which in the current study were analyzed in the glandular region of the stomach (part that is exposed to the highly corrosive acidity of gastric juice). Four main types of epithelial cells cover the surface of the glandular stomach and extend down into the gastric pits and glands. These include mucus-secreting cells, parietal (oxyntic) cells that produce $\mathrm{HCl}$, peptic (chief) cells that secrete proteolytic enzyme pepsin and $\mathrm{G}$ (gastrin) cells that synthesize peptide hormone gastrin. Damage to the stomach mucosa leads to impaired function and pain and has often been associated with complications such as gastric bleeding, perforation and obstruction (Milosavljevic et al., 2011).

Gastric ulceration is a common cause of morbidity and mortality, with close to 53 million people developing gastric ulcers in the world each year (Global Burden of Disease Study 2013 Collaborators, 2015). The conventional treatment of gastric ulcers involves use of proton pump inhibitors such as omeprazole and histamine- 2 receptor antagonists like ranitidine, both of which act by reducing gastric acid secretion (Fernandes \& Marinho, 2019). These drugs are often used in combination with antibiotics, particularly those that have activity against $\mathrm{H}$. pylori (Gisbert

\footnotetext{
${ }^{1}$ Department of Veterinary Anatomy and Physiology, Faculty of Veterinary Medicine, University of Nairobi, Riverside Drive, P.O. Box 30197- 00100, Nairobi, Kenya.

${ }^{2}$ Department of Plant Science and Crop Protection, Faculty of Agriculture, University of Nairobi, P.O. Box 29053- 00625, Kangemi, Nairobi, Kenya. Grant: National Research Fund, Kenya, No. 58/ 2016
} 
MUREITHI, P. M.; KAVOI, B. M.; ONYANGO, C. M. \& MATHIU, M. P. Antiulcerogenic effects of selected African nightshades (Solanum nigrum linn.) genotypes on the rat stomach: A morphologic and morphometric study. Int. J. Morphol., 38(4):940-946, 2020.

et al., 2000). Antibiotic resistance is on the rise and as such, management of gastric ulcers through the above methods is a serious challenge (Wang \& Peura, 2011). Other drugs used to treat gastric ulcers are prostaglandin analogues, antimuscarinics and antacids (LoIudice et al., 1981). Use of the aforementioned drugs are associated with adverse effects including arrhythmias (Marcus et al., 2010) and hematopoietic changes (Odou et al., 1999) which appear to limit their use and to trigger the search for alternative drugs.

Medicinal plants are used in the management and treatment of many disease conditions and their use dates back to human civilization (Khan, 2014). The widespread use of medicinal plants has been linked to their ease of accessibility and the common belief that they are less toxic than allopathic drugs (Ernst \& Hung, 2011). In developing countries, aproximately four billion people rely on herbal products for their healthcare needs (Bodeker et al., 2005). Solanum nigrum (SLN) belongs to the family Solanaceae and is characterized by alternate leaves with smooth margins, small and white or pale violet flowers, and green or black berries that grow in bunches (Edmonds \& Chewya, 1997). In Kenya and other parts of Africa, this plant is widely used as a vegetable and in managing a host of ailments including gastric ulcers (Edmonds \& Chweya). SLN grown and utilized in Kenya occur in different genotypes/ ecotypes. Thus this study analyzes, through morphologic and morphometric means, the antiulcerogenic potential of some of the Kenyan genotypes in preventing gastric ulceration in the rat.

\section{MATERIAL \& METHOD}

Plants collection: Three SLN genotypes namely, S. scabrum (SSB), S. sarrachoides (SSR) and S. villosum (SVL), were collected from the Kenya Agricultural Research Institute (KARI), Muguga, which is located $27 \mathrm{~km}$ North West of Nairobi and lies $2096 \mathrm{~m}$ above sea level. The rainfall here is bimodal and ranges between 900 and $1000 \mathrm{~mm}$ annually. Long rains of about $550 \mathrm{~mm}$ are experienced between March and June while short rains of about $400 \mathrm{~mm}$ fall between October and December. The temperature ranges between 7 ${ }^{\circ} \mathrm{C}$ and $20^{\circ} \mathrm{C}$ with a mean of $15^{\circ} \mathrm{C}$. The area has well drained reddish brown to dark red soil (FAO, 2006). Authentication of the SLN genotypes collected from KARI was performed by a botanist at the Botany Section of the School of Biological Sciences, University of Nairobi.

Preparation of plant extracts: Leaves from the various SLN genotypes were harvested green and dried in shed, with constant turning over to avert fungal growth. After seven days of drying, the leaves were pulverized into fine powder using an electric blender. $100 \mathrm{~g}$ of each of the powdered leaves was boiled in $500 \mathrm{ml}$ of water for 15 minutes. The aqueous extract was then sieved, dried under vacuum in a VirTis Freeze Dryer and the residue weighed and stored at $-20{ }^{\circ} \mathrm{C}$ until required for testing. Oral doses for the animals were prepared (on the basis of body weight) by dissolving the dried extract in $10 \mathrm{ml}$ of distilled water just before administration.

Experimental animals. A total of 30 adult male Wistar rats (220-250 g) were used for this study. These rats were from a stock bred at the Department of Veterinary Anatomy animal facility, where housing of the rats was done in cages with raised floors of wide wire mesh (to prevent coprophagy). Here, the animals were raised under conditions of 12L: 12D cycle, temperature $23 \pm 2{ }^{\circ} \mathrm{C}$ and humidity $55 \pm 15 \%$ and with provision of a balanced diet and free access to water. All protocols for experimentation of the animals were approved by the Biosafety, Animal Use and Ethics Committee of the Faculty of Veterinary Medicine, University of Nairobi (FVM BAUEC/2016/1120) and strictly conformed to the Animals (Scientific Procedures) Act 1986.

Administration of substances to the animals. SLN extract dosage used in this study was selected on the basis of an acute toxicity test earlier carried out in mice (Khazaei \& Salehi, 2006). To ensure an empty stomach before administration of the different substances, rats in all groups were fasted for 48 hours, but with provision of a nutritive solution of $8 \%$ sucrose in $0.2 \% \mathrm{NaCl}$ (until $1 \mathrm{hr}$ before administration of the substances) to avoid excessive dehydration during the fasting period (Glavin \& Mikhail, 1976). All substances were administered to the animals orally using a stainless intubation needle.

The rats were randomly allotted to five groups of six animals each. Group 1 was the positive control and rats in this group were administered $10 \mathrm{ml} / \mathrm{kg}$ distilled water prior to ulcer induction. Groups 2, 3 and 4 were the test animals and these received SLN extracts from SSB, SSR and SVL, respectively, at a dose rate of $500 \mathrm{mg} / \mathrm{kg}$ and at three different intervals: two doses on the first day at 08:00 $\mathrm{h}$ and 16:00 $\mathrm{h}$ and a third dose on the second day, $1.5 \mathrm{~h}$ before ulcer induction. Group 5 rats were kept as negative/ normal controls (i.e. ulcer induction was not done on them) and these were administered distilled water of equivalent volume to that of the extract administered to the test animals, and only at the same time intervals as the test animals (Glavin \& Mikhail).

Gastric ulcer induction and harvesting of the stomachs. Induction of gastric ulceration was done on positive control rats (group 1) and the test rats (groups 2-4) using ethanol 
(Merck) $50 \%(\mathrm{v} / \mathrm{v})$ (in distilled water) at a dose rate of 10 $\mathrm{ml} / \mathrm{kg}$ given orally via an intubation needle (Glavin \& Mikhail). One hour after ethanol-ulcer induction, all animals were sacrificed by intraperitoneal injection of lethal doses of pentobarbital sodium (140 mg/kg bwt). This was followed by perfusion fixation via the heart with $10 \%$ formaldehyde and subsequent removal of the stomach, which was opened along its greater curvature and gently rinsed in physiological saline.

Macroscopic analysis of the stomachs. The glandular parts of stomachs of rats in all groups were grossly examined and measurements of lesions done under an illuminated magnifying microscope (at 10x) in order to determine the ulcerative index and the percentage ulcer inhibition/ prevention scores as detailed in Alkofahi \& Atta (1999). To this end, long lesions were counted and measured along their greater lengths while petechial lesions were counted with the aid of a 1-mm square grid, with each five petechial lesions being considered as $1 \mathrm{~mm}$ of ulcer. The sum of the total length of ulcers in each group of rats was divided by its number to obtain the ulcer index (in $\mathrm{mm}$ ). Where MaUI denotes macroscopic ulcer index, macroscopic ulcer prevention (MaUP) ratio was worked out and expressed as a percentage using the formula:

\section{MaUP $=[($ Control MaUI - Test MaUI $) /$ Control MaUI $]$ x 100}

Microscopic analysis of the stomachs. Soon after gross evaluation, the stomachs were further fixed by immersing them in $10 \%$ formaldehyde after which small pieces of the glandular parts were harvested from the antral region. These were further sliced into smaller subsegments and sampled randomly for routine histologic processing. $5 \mathrm{~mm}$ sections were cut from the selected subsegments and stained by H\&E, Masson's trichrome and PAS methods. The stained sections were then analyzed on a Leica DRM light microscope connected to a monitor. Microscopic Ulcer Index (MiUI) was obtained on a scale of 0 to 3 as described in Khazaei \& Salehi. Where $0=$ normal tissue, $1=$ local damage to gastric pit cells, 2= local damage to gastric glands and 3= deep damage to gastric glands, the MiU (in $\mathrm{mm}$ ) was calculated as follows:

MiUI $=($ no. lesions 1$)+($ no. lesions 2$) \times 2+($ no. lesions 3$)$ $\times 3$

Data analysis. Data were analyzed using one way analysis of variance (ANOVA) and Dunnett's pair wise test for intergroup differences. Differences were regarded as significant when $\mathrm{p}<0.05$. In all cases, data were presented as mean $\pm \mathrm{SD}$.

\section{RESULTS}

Gross anatomical findings. Figure 1 shows the magnitude of lesions on the mucosa after ulcer induction and harvesting of the rat stomachs. Positive control rats (those that received distilled water before ulcer induction) presented the most numerous and extensive mucosal lesions. Additionally in this group, the stomachs were markedly congested, hemorrhagic and edematous. Rats pretreated with SLN extracts from SSB, SSR and SVL showed less gastric lesions than controls (Fig. 1).
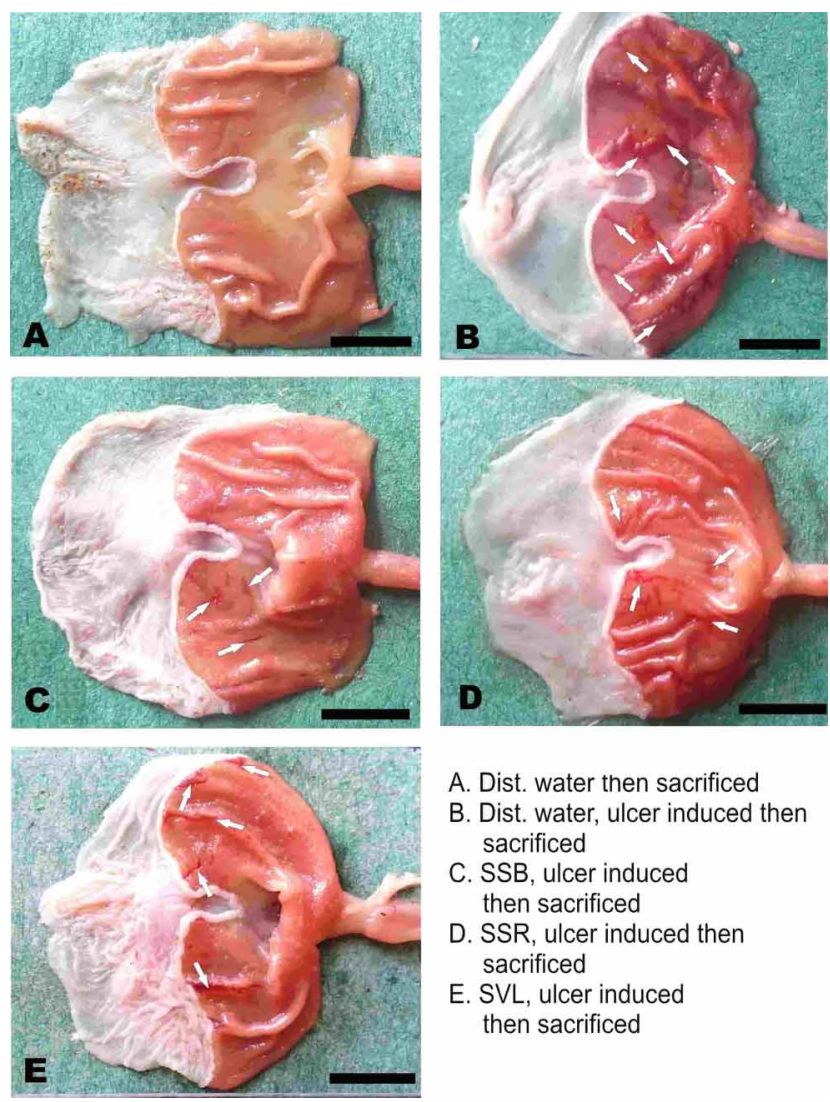

A. Dist. water then sacrificed

B. Dist. water, ulcer induced then sacrificed

C. SSB, ulcer induced then sacrificed

D. SSR, ulcer induced then sacrificed

E. SVL, ulcer induced then sacrificed

Fig. 1. Macrographs of stomachs of rats from the five different groups. A: Negative control rats that received only distilled water before euthanasia. B: Positive control rats administered distilled water before ulcer induction. C-E: Pretreated respectively with SSB, SSR and SVL before ulcer induction. Notice the absence of lesions in A and the massive gastric ulcerations (arrows) in B. There is evidence of ulcer protection by all SLN genotypes as revealed by the marked reduction in number of ulcerative areas (arrows), with the most effective extract being SSB followed by SSR and then $\mathrm{SVL}$, scale bar $=1 \mathrm{~cm}$.

In Table I, morphometric data on ulcerative index and ulcer inhibition values are provided in positive control and SLN-pretreated animals. In the control rats, the 
macroscopic ulcer index was estimated at $13.46 \pm 2.03 \mathrm{~mm}$ while in the SLN-pretreated group, the magnitude of gastro protection against ulceration varied with genotype, with the percentage ulcer inhibition scores being $76.37,72.51$ and 63.30 in SSB, SSR and SVL, respectively.
Light microscopic findings. Microscopic view of the rat stomach in negative (normal) controls is presented in Figure 2. These illustrations serve to guide the reader on how depths of penetrating ulcers were traced and graded when working out ulcer index values at light microscopy. The

Table I. Protective effects of extracts from S. scabrum, S. sarrachoides (SSR) and S. villosum (SVL) on ethanol induced gastric lesions in rats. Values are means $\pm S D, n=6$ / group.

\begin{tabular}{lccc}
\hline Treatment & $\begin{array}{l}\text { Macroscopic } \\
\text { Ulcer Index }(\mathrm{mm})\end{array}$ & $\begin{array}{l}\text { Microscopic } \\
\text { Ulcer Index (mm) }\end{array}$ & Ulcer inhibition (\%) \\
\hline +ve control- water then ulcer induction & $13.46 \pm 2.03$ & $14.5 \pm 2.17$ & \\
SSB then ulcer induction & $3.18 \pm 0.64$ & $2.86 \pm 0.44$ & 76.37 \\
SSR then ulcer induction & $3.70 \pm 0.73$ & $4.08 \pm 0.75$ & 72.51 \\
SVL then ulcer induction & $4.94 \pm 0.81$ & $6.12 \pm 0.83$ & 63.30 \\
\hline
\end{tabular}
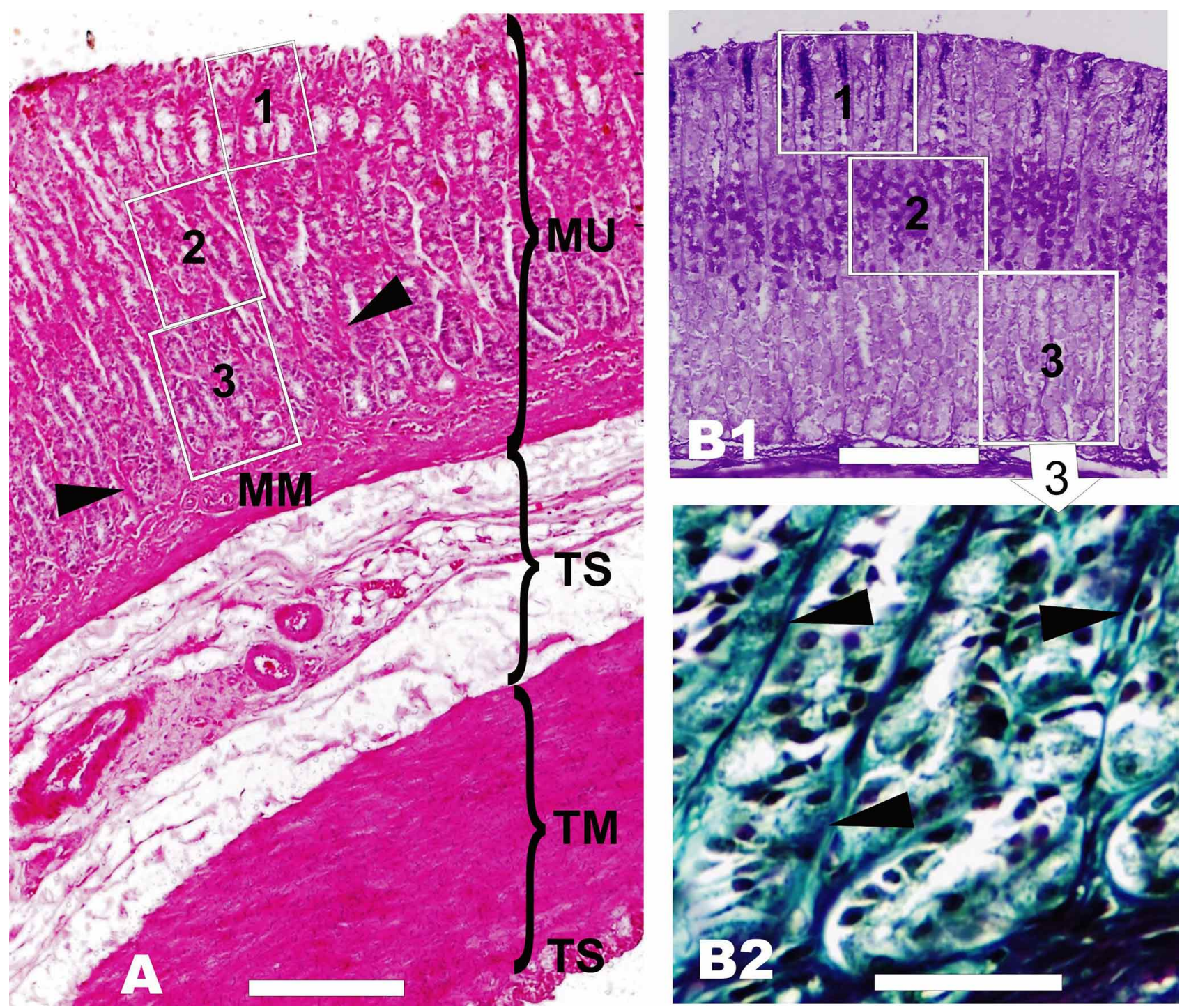

Fig. 2. Microscopic view of the stomach wall in negative control rats A: Wall layers: tunica mucosa (MU) and its muscularis mucosa (MM), tunica submucosa (TS), tunica muscularis (TM) and tunica serosa (TS). A\&B1: boxes show the regions of gastric gland pits (1), neck (2) and body (3). In B1, mucus-secreting cells of the gastric pits (1) stain more deeply with PAS as compared to those of the neck (2). Notice also (in A and more clearly in B2) the strands of muscularis mucosa (arrow heads) that extend apically to lie between the glands. A-H \&E, B1-PAS, B2- Masson's trichrome stain, scale bar $=200 \mu \mathrm{m}$ in A \& B and $50 \mu \mathrm{m}$ in C. 

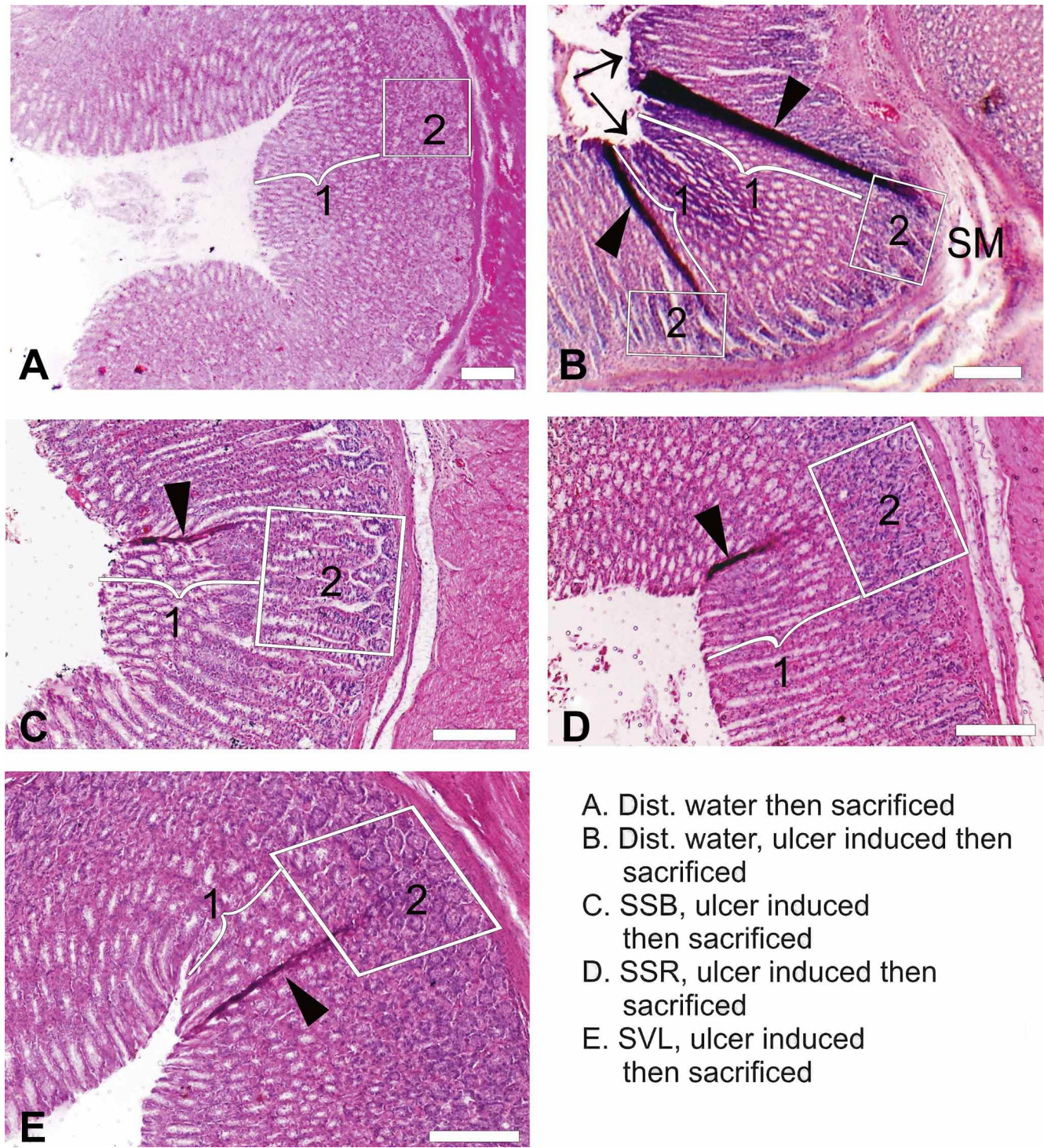

A. Dist. water then sacrificed

B. Dist. water, ulcer induced then sacrificed

C. SSB, ulcer induced then sacrificed

D. SSR, ulcer induced then sacrificed

E. SVL, ulcer induced then sacrificed
Fig. 3. Histomicrographs showing the degree of ulceration in the five groups of rats. Group A rats received only water before euthanasia and show no lesions. Rats in group B received water before ulcer induction. These present relatively more closely spaced ulcers (arrow heads) that begin as focal areas of erosion (arrows) on the mucosal surface and then penetrate deep through the gastric pits (1) and glands (2) to end at the tunica submucosa (SM). Groups C-E are the SSB, SSR and SVL pretreated animals, respectively. Mucosal surface erosion in these groups is relatively minimal and the penetrating ulcers only affect the gastric pits except in $\mathrm{C}$ where ulcers slightly extend to the upper gastric gland region. $\mathrm{H} \& \mathrm{E}$ stain, scale bar $=200 \mu \mathrm{m}$ in A-E. stomach wall is typified, like in other mammals, by a tunica mucosa, submucosa, muscularis and serosa, and with the mucosa having glands that presented distinct pit, neck and body regions. Strands of muscularis mucosa were observed to extend apically in between individual gastric glands (Fig. 2).

In Figure 3, the degree of glandular lesions is demonstrated at histological level. Positive control rats (those administered distilled water before ulcer induction) showed closely spaced glandular lesions on the mucosal surface. Penetrating ulcers in this group of rats pierced through the gastric pits and glands to terminate at the tunica submucosa. In rats pretreated with SSB, SSR and SVL extracts, gastric mucosal surface erosions were notably few and the penetrating ulcers only affect the gastric pits except for SVL where the ulcers extended to the upper region of the gastric glands (Fig. 3). Quantitatively (Table I), microscopic ulcer index in positive controls was $14.5 \mathrm{~mm}$, a value that decreased to 2.86 in SSV, 4.08 in SSR and 6.12 in SVL- treated rats.

Figure 4 is a higher magnification focusing on ulcerated areas of gastric mucosa of positive control rats (i.e. those that received distilled water before ulcer induction). Here, the type of lesions encountered included: (i) mucosal erosion whose interval of occurrence was relatively short (also in Fig. 3), (ii) penetrating ulcers that dug through the pits, neck and body of the gastric glands to reach the muscularis mucosa and to a lesser extent, the tunica submucosa, (iii) death of gastric gland cells, including peptic and parietal cells, in areas of the mucosa penetrated by the ulcers and (iv) degenerative changes involving parts of the muscularis mucosa that were penetrated by ulcers. 


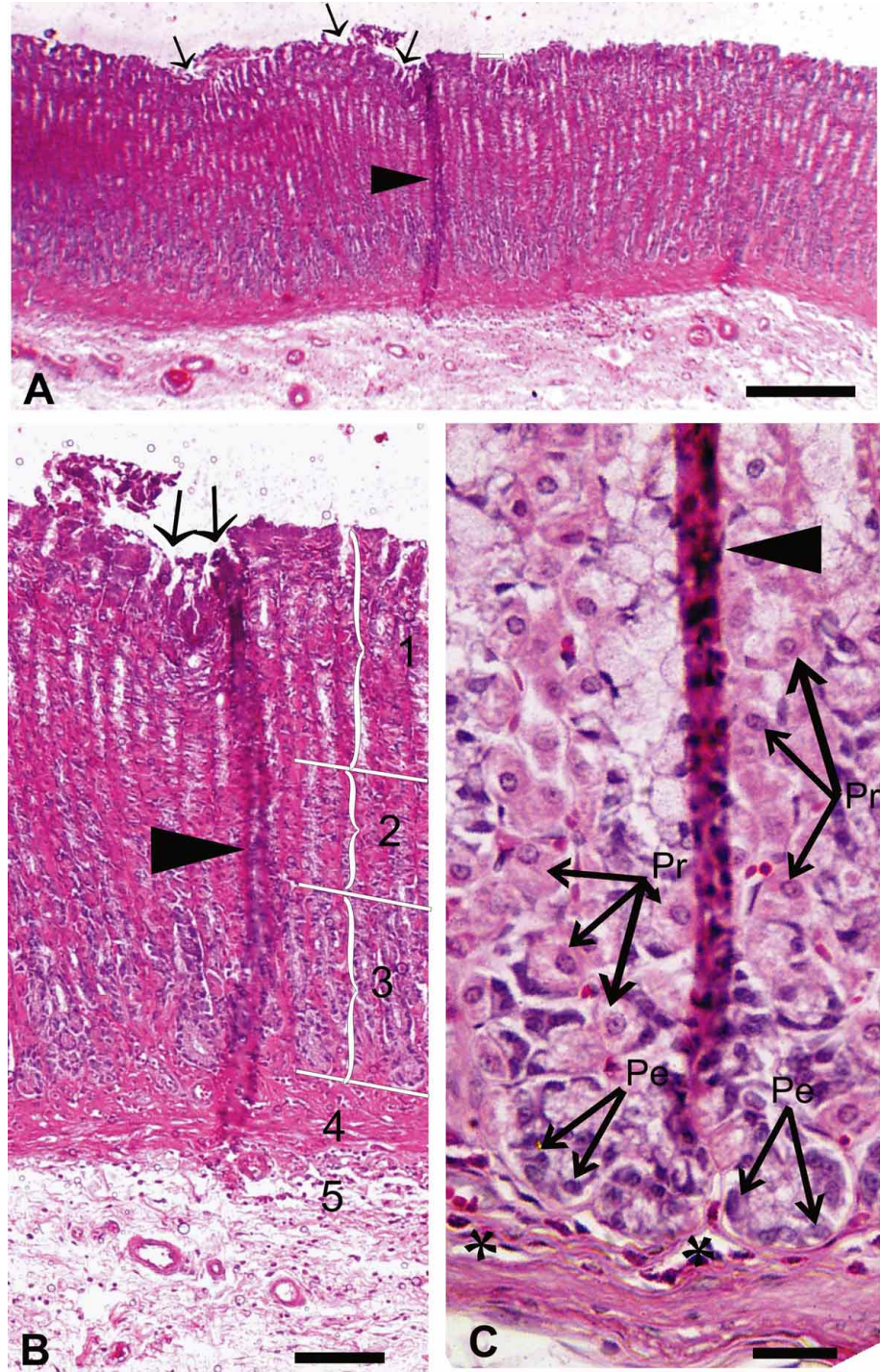

Fig. 4. A higher magnification focusing on ulcerated areas of gastric mucosa of positive control rats (i.e. those that received distilled water before ulcer induction). In A and B, areas of gastric mucosal surface erosion (arrows) occur at fairly short intervals. Penetrating ulcers (arrow heads) enter through the gastric pits (1), neck (2) and fundus/ body (3) of the gastric glands, muscularis mucosa (4) and to slightly extend, the tunica submucosa (5). More deeply, in $\mathrm{C}$, the penetrating ulcer results in localized cell death involving peptic $(\mathrm{Pe})$ and parietal cells $(\mathrm{Pr})$ as well as degenerative changes (asterisks) in the muscularis mucosa. $\mathrm{H} \& \mathrm{E}$, scale bar in $\mathrm{A}, \mathrm{B} \& \mathrm{C}=300$, $100 \& 40 \mu \mathrm{m}$ respectively.

\section{DISCUSSION}

This study provides, for the first time, experimental data on the impact of aqueous leaf extracts of SLN genotypes SSB, SSR and SVL in a rat model. Our findings revealed that extracts of the above SLN genotypes protect against ethanolinduced gastric ulceration at varied strengths, with SSB being more effective (ulcer inhibition $=76.37 \%$ ) compared to SSR $(71.51 \%)$ and SVL $(63.30 \%)$. Our results on antiulcerogenic capacities of the three genotypes of SLN compare favorably with those of earlier investigators. In the study by Saravanan et al. (2011) in which antiulcerogenic effects were analyzed for methanolic extracts of SLN grown in India using asprin and cold restraint stress as ulcer inducers, respective ulcer inhibition rates were $77.85 \%$ and $66.67 \%$. The study by Jainu \& Devi (2004) assessed methanolic extracts of berries of an Indian SLN for gastro protection against aspirin-induced ulcerations in rats and reported ulcer inhibition scores of 49.30, 70.12 and $72.70 \%$ for extract doses of 250,500 and $1000 \mathrm{mg} / \mathrm{kg}$ respectively.

In the literature, data have also been provided on allopathic drugs ranitidine and famotidine, both $\mathrm{H} 2$ antihistamines that act by reducing $\mathrm{HCl}$ secretion by parietal cells (Sachs \& Scott, 2016). In rats, the percentage inhibition of gastric ulceration by ranitidine in ethanol-induced ulceration is 58.51 (Khazaei \& Salehi) while that of famotidine in asprin induced ulcers is 88.91 (Saravanan et al.). The mechanism of ulcer induction on the gastric mucosa by ethanol entails a host of events including massive production of free radicals and consequential increase in lipid peroxidation which lead to damage of cells and their membranes (Shetty et al., 2000). Tannins, terpenes and fatty acids are some phytoconstituents identified in plants that show gastro protective activity against ulcers (Leite $e t$ al., 2009). Hydroxyl radical scavenging and the resultant reduction in lipid peroxidation to offer cytoprotection is the most probable mechanism of action of the aforementioned phytochemicals (Prashanth Kumar et al., 2001). Indeed, we observed here that extracts of the three Kenyan SLN genotypes inhibited ethanol-induced gastric injuries including congestion, hemorrhage, edema and ulcerations in the rat. In the SLN-pretreated animals, light microscopy using H\&E, Masson's trichrome and PAS revealed less penetrating ulcers as well as minimal degeneration of specific gastric gland cells.

In conclusion, this study established that extracts of SLN genotypes SSB, SSR and SVL provides protection against gastric ulceration. The antiulcerogenic potential, when accessed in terms of ulcer index and percentage ulcer inhibition showed genotype-dependent differences. The differences in ulcer inhibition scores may be attributed to genetic factors, which reportedly influence the nature and composition of bioactive ingredients synthesized in medicinal plants (Sharma \& Sarkar, 2013). Plausibly, data generated from this work provide additional 
knowledge for the popular use of this plant as an antiulcer remedy in Kenyan folk medicine. Future follow up studies should incorporate more SLN genotypes and focus on identifying toxic chemical moiety (-ies) of the extracts, if any, and their specific adverse effects, both short and long term.

ACKNOWLEDGEMENTS. We thank Amos Tangai, Francis Okumu and Peter Kiguru of Veterinary Anatomy \& Physiology and Sarah Mungania of Human Anatomy for their excellent technical assistance. This work was funded by the National Research Fund, Kenya (Grant No. 58, 2016).

MUREITHI, P. M.; KAVOI, B. M.; ONYANGO, C. M. \& MATHIU, M.P.Efectos antiulcerogénicos de genotipos seleccionados de solanáceas africanas (Solanum nigrum Linn.) en el estómago de ratas: Un estudio morfológico y morfométrico. Int. J. Morphol., 38(4):940-946, 2020.

RESUMEN: Solanum nigrum (SLN), comúnmente conocida como la solanácea africana, se usa como vegetal, para el tratamiento de diversas dolencias incluyendo las úlceras gástricas. Analizamos de forma macro y microscópica, de forma macroscópica y microscópica, utilizando para ello tinciones de H\&E, tricrómico de Masson y PSA los efectos protectores de extractos acuosos de hojas de tres genotipos SLN de Kenia: S. scabrum (SSB), S. sarrachoides (SSR) and S. villosum (SVL) en lesiones gástricas inducidas por etanol en ratas. Hubo evidencia de gastroprotección por parte de los tres genotipos con el SSB mostrando el puntaje más alto de inhibición de la úlcera $(76,37 \%)$ seguido de SSR $(72,51 \%)$ y SVL $(63,30 \%)$. Las ratas tratadas previamente con SLN mostraron menos áreas de erosión de la superficie de la mucosa gástrica. Además, en los animales pretratados, la profundidad de las úlceras se redujo notablemente, llegando solo a la región del fondo gástrico, excepto en aquellos tratados con SVL donde las úlceras penetraron un poco más profundamente para afectar las glándulas gástricas. En comparación con los controles, el índice medio de úlcera microscópica disminuyó 5,07, 3,55 y 2,37 veces en ratas pretratadas con extractos de SSB, SSR y SVL, respectivamente. Los resultados de este trabajo muestran que los extractos de los tres genotipos de SLN tienen potencial antiulcerogénico en diferentes concentraciones, lo que confirma informes anteriores que los fitoconstituyentes y la eficacia de una planta medicinal pueden estar influenciados por factores genéticos.

PALABRAS CLAVE: Úlcera gástrica; Inhibición; Kenia; Solanum nigrum.

\section{REFERENCES}

Alkofahi, A. \& Atta, A. H. Pharmacological screening of the anti-ulcerogenic effects of some Jordanian medicinal plants in rats. J. Ethnopharmacol., 67(3):341-5, 1999.

Bodeker, C.; Bodeker, G.; Ong, C. K.; Grundy, C. K.; Burford, G. \& Shein, K. WHO Global Atlas of Traditional, Complementary and Alternative Medicine. Geneva, World Health Organization, 2005.

Edmonds, J. M. \& Chweya, J. A. Black Nightshades: Solanum nigrum L. and Related Species, Vol. 15. Rome, International Plant Genetic Resources Institute, 1997.

Ernst, E. \& Hung, S. K. Great expectations: what do patients using complementary and alternative medicine hope for? Patient, 4(2):89-101, 2011.
Fernandes, S. R. \& Marinho, R. T. The dark side of the long-term use of proton pump inhibitors in chronic liver disease. Port. J. Gastroenterol., 26:79-80, 2019

Gisbert, J. P.; Blanco, M.; Cruzado, A. I. \& Pajares, J. M. Helicobacter pylori infection, gastric metaplasia in the duodenum and the relationship with ulcer recurrence. Eur. J. Gastroenterol. Hepatol., 12(12):1295-8, 2000.

Glavin, G. B. \& Mikhail, A. A. Stress and ulcer etiology in the rat. Physiol. Behav., 16(2):135-9, 1976.

Global Burden of Disease Study 2013 Collaborators. Global, regional, and national incidence, prevalence, and years lived with disability for 301 acute and chronic diseases and injuries in 188 countries, 1990-2013: a systematic analysis for the Global Burden of Disease Study 2013. Lancet, 386(9995):743-800, 2015.

Greaves, P. Histopathology of Preclinical Toxicity Studies: Interpretation and Relevance in Drug Safety Evaluation. $4^{\text {th }}$ ed. Cambridge, Academic Press, 2012.

Jainu, M. \& Devi, C. S. Antioxidant effect of methanolic extract ofSolanum nigrum berries on aspirin induced gastric mucosal injury. Indian J. Clin. Biochem., 19(1):57-61, 2004.

Khan, H. Medicinal plants in light of history: recognized therapeutic modality. $J$. Evid. Based Complementary Altern. Med., 19(3):216-9, 2014.

Khazaei, M. \& Salehi, H. Protective effect of Falcaria vulgaris extract on ethano induced gastric ulcer in rat. Iran. J. Pharmacol. Ther., 5:43-6, 2006.

Leite, G. O.; Penha, A. R. S.; da Silva, G. Q.; Colares, A. V.; Rodrigues, F. F. G.; Costa, J. G. M.; Cardoso, A. L. H. \& Campos, A. R. Gastroprotective effect of medicinal plants from chapada do araripe, Brazil. J. Young Pharm., 1(1):54-6, 2009.

Loludice, T. A.; Saleem, T. \& Lang, J. A. Cimetidine in the treatment of gastric ulcer induced by steroidal and nonsteroidal anti-inflammatory agents. Am. $J$. Gastroenterol., 75(2):104-10, 1981.

Marcus, G. M.; Smith, L. M.; Scheinman, M. M.; Badhwar, N.; Lee, R. J.; Tseng, Z. H.; Lee, B. K.; Kim, A. \& Olgin, J. E. Proton pump inhibitors are associated with focal arrhythmias. J. Innov. Card. Rhythm Manag., 1:85-9, 2010.

Milosavljevic, T.; Kostic-Milosavljevic, M.; Jovanovic, I. \& Krstic, M Complications of peptic ulcer disease. Dig. Dis., 29(5):491-3, 2011.

Moore, R. A.; Derry, S.; Simon, L. S. \& Emery, P. Nonsteroidal anti-inflammatory drugs, gastroprotection, and benefit-risk. Pain Pract., 14(4):378-95, 2014.

Odou, P.; Martin, P.; Membré, S.; Gressier, B.; Tamiji, L.; Dine, T.; Luyckx, M. M.; Brunet, C.; Dhee, D. \& Moulron, S. Omeprazole-induced leukopenia. A case report. J. Clin. Pharm. Ther, 24(5):317-21, 1999

Prashanth Kumar, V.; Shashidhara, S.; Kumar, M. M. \& Sridhara, B. Y. Cytoprotective role of Solanum nigrum against gentamicin-induced kidney cell (Vero cells) damage in vitro. Fitoterapia, 72(5):481-6, 2001.

Sabiu, S.; Garuba, T.; Sunmonu, T.; Ajani, E.; Sulyman, A.; Nurain, I. \& Balogun, A. Indomethacin-induced gastric ulceration in rats: Protective roles of Spondias mombin and Ficus exasperata. Toxicol. Rep., 2:261-7, 2015

Sachs, G. \& Scott, D. R. Letter: vonoprazan, a long-lasting acid suppressor of the gastric $\mathrm{H}+, \mathrm{K}+$-ATPases with - implications for renal $\mathrm{H}+, \mathrm{K}+$-ATPases; authors' reply. Aliment. Pharmacol. Ther, 43(3):443, 2016.

Saravanan, S.; Dhasarathan, P.; Indira, V. \& Venkatraman, R. Gastro protective and antioxidant activity of Solanum nigrum Linn. against aspirin and cold restraint stress induced ulcerated rats. Res. J. Immunol., 4(1):1-11, 2011.

Sharma, V. \& Sarkar, I. N. Bioinformatics opportunities for identification and study of medicinal plants. Brief. Bioinform., 14(2):238-50, 2013.

Shetty, R.; Kumar, K. V.; Naidu, M. U. R. \& Ratnakar, K. S. Effect of gingko biloba extract on ethanol-induced gastric mucosal lesions in rats. Indian J. Pharmacol., 32:313-7, 2000

Wang, A. Y. \& Peura, D. A. The prevalence and incidence of Helicobacter pyloriassociated peptic ulcer disease and upper gastrointestinal bleeding throughout the world. Gastrointest. Endosc. Clin. N. Am., 21(4):613-35, 2011.

Corresponding author:

Boniface M. Kavoi (PhD)

Department of Veterinary Anatomy and Physiology

Faculty of Veterinary Medicine

University of Nairobi

Riverside Drive, P.O. Box 30197- 00100

Nairobi - KENYA

Email: drkanvo@yahoo.com

Received: 06-02-2020

Accepted: 23-03-2020 